\title{
STATUS OF THE GANGES RIVER SHARK GLYPHIS GANGETICUS (MÜLLER \& HENLE, 1839)
}

\author{
Gawsia W Chowdhury*, Muntasir Akash ${ }^{1}$ and Alifa Bintha Haque ${ }^{1}$ \\ Department of Zoology, University of Dhaka, Dhaka-1000, Bangladesh
}

Key words: Sharks, Glyphis, Critically endangered, Sundarbans

A rarest shark in the world has been recorded from the rivers and estuaries of Bangladesh ${ }^{(1,2)}$. This shark species is known as Ganges River Shark Glyphis gangeticus (Müller \& Henle, 1839) which is one of the three confirmed, and three or more to be described river shark species under the genus Glyphis(2). This is the nominal species of the genus, with a handful of specimens so far known, comprehends the world's one of the most elusive and the most threatened shark taxa, nonetheless, a natural marvel of the Ganges Delta on the brink of extinction ${ }^{(1)}$. The objectives of this effort for Ganges River Shark are to provide an annotation of references under single compilation. This study will highlight a need to bring this species under conservation attention.

Belonging to the family Carcharhinidae, Glyphis species are used to be named as river sharks due to euryhyaline adaptation with a tendency to be reported from inter-tidal zone (species from Eastern Australia and Papua New Guinea) to zero salinity areas (Ganges Delta and westward rivers). River sharks, other than the Bull Shark Carcharhinus leucus, are the only known shark species tolerant to low salinity and even freshwaters ${ }^{(2,3)}$.

Though originally described about two centuries ago, it is to be enumerated that last confirmed record of this species is from a specimen collected $84 \mathrm{~km}$ upstream of the mouth of the Hooghli River, at Mahishadal, in 2001, based on photographs of the jaw ${ }^{(4)}$. The species is known to science only from three museum specimens (one each in the Museum National d'Histoire Naturelle, Paris; Humboldt Museum, Berlin and Zoological Survey of India, Calcutta), all of which were collected in the 19th century ${ }^{(1,4)}$. Narrowing the sphere down to geographical boundary of Bangladesh(5), the last confirmed record of Ganges Shark is dated back to 1969 though identification was disputed. This can either be because of lack of identification guides and ambiguous identification amongst the fishers, inadequate species specific research or small population size.

The species has been considered under the class: Chondrichthyes Huxley, 1880; subclass: Elasmobranchii Bonaparte, 1838; order: Carcharhiniformes, Compagno, 1977; family: Carcharhinidae, Jordan \& Evermann, 1896; genus: Glyphis Agassiz, 1843; and under the species Glyphis gangeticus (Müller \& Henle, 1839). The species is commonly identified as Ganges Shark whereas locally it is known as Nodir Hangor and Kamot.

*Author for correspondence: <gawsia@gmail.com>. 
Of genus Glyphis, only G. gangeticus holds the unanimous taxonomic status trailed by G. garricki, G. glyphis and G. siamensis, though sometimes the latter is considered as synonym of G. gangeticus ${ }^{(3)}$. Glyphis sharks are typical of carcharhinid sharks ${ }^{(2,6)}$ with an estimated body length of up to two meters; short, broadly rounded snouts making it closely resembling to the similar short-snouted Bull Shark; small, wide-spaced nostrils, no spiracles, labial furrows confined to mouth corners; extremely small eyes; eyes tilted upwards which is unlikely of other requiem sharks, thought to be an adaptability to scan the water above for preys backlit by the sun; serrated triangular, broad-cusped upper teeth (teeth formation on jaws is a vital identification key); conspicuously protruding cusps on lower teeth; no keels on caudal peduncle; longitudinal precaudal pits, first dorsal midbase much closer to pectoral bases than pelvic; second dorsal fin half to $3 / 5$ height of first; second dorsal origin slightly in front of anal origin; anal fin with pre-anal ridges virtually absent and with a deeply notched posterior margin. These traits have made Glyphis gangeticus a strong look-alike with its congeners and carcharhinid species Bull Shark (Fig. 1).

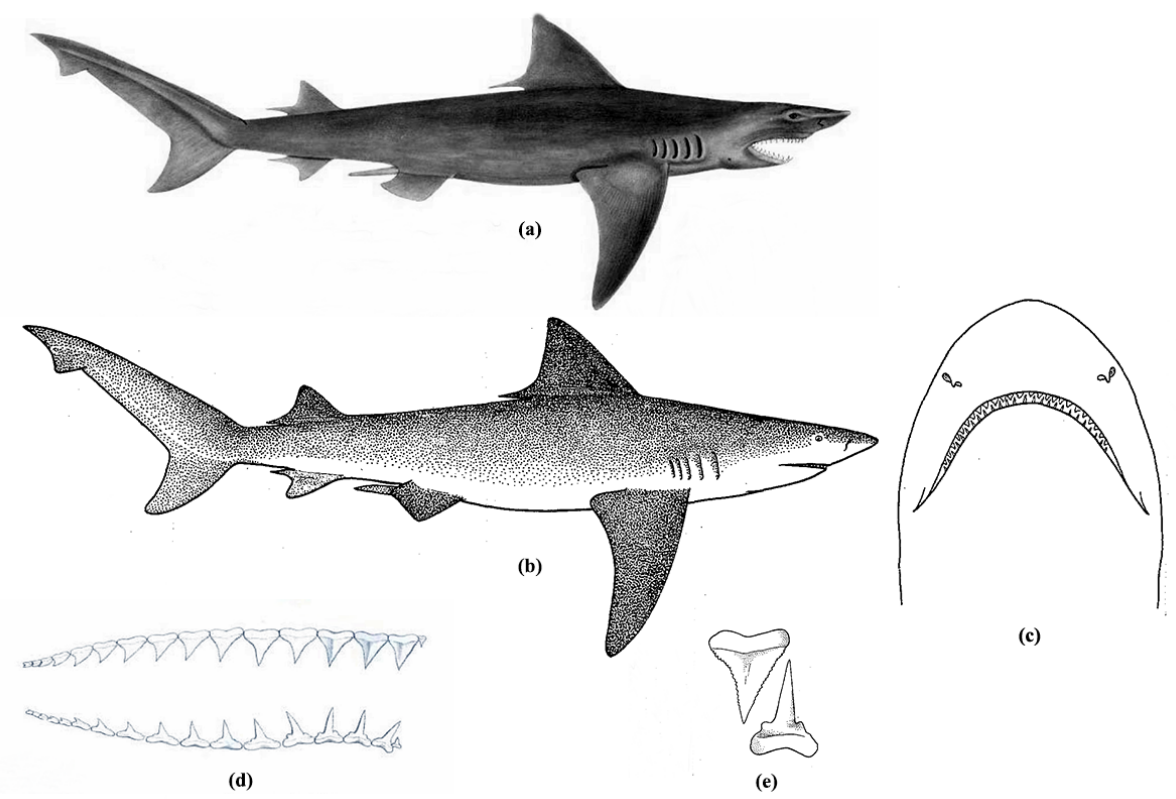

Fig. 1. Morphological characteristics of Ganges Shark Glyphis gangeticus (Müller \& Henle, 1839). (a) physical appearance, (b) sketch, (c) underside of head, (d) formation of teeth along jaw and (e) tooth shape ${ }^{(6,8)}$.

Identification up to species level for Glyphis is tricky oriented with subtle morphological and anatomical traits (Fig. 1)(4). G. gangeticus differentiates from G. glyphisG. siamensis complex and other to be described specimens because of first few anterior 
teeth in lower jaw with entire smooth cutting edges; low cusplets on the crown feet; lower second dorsal fin being about half height of first dorsal; total vertebrae number limited to 170 with species-specific arrangement along the vertebral column.

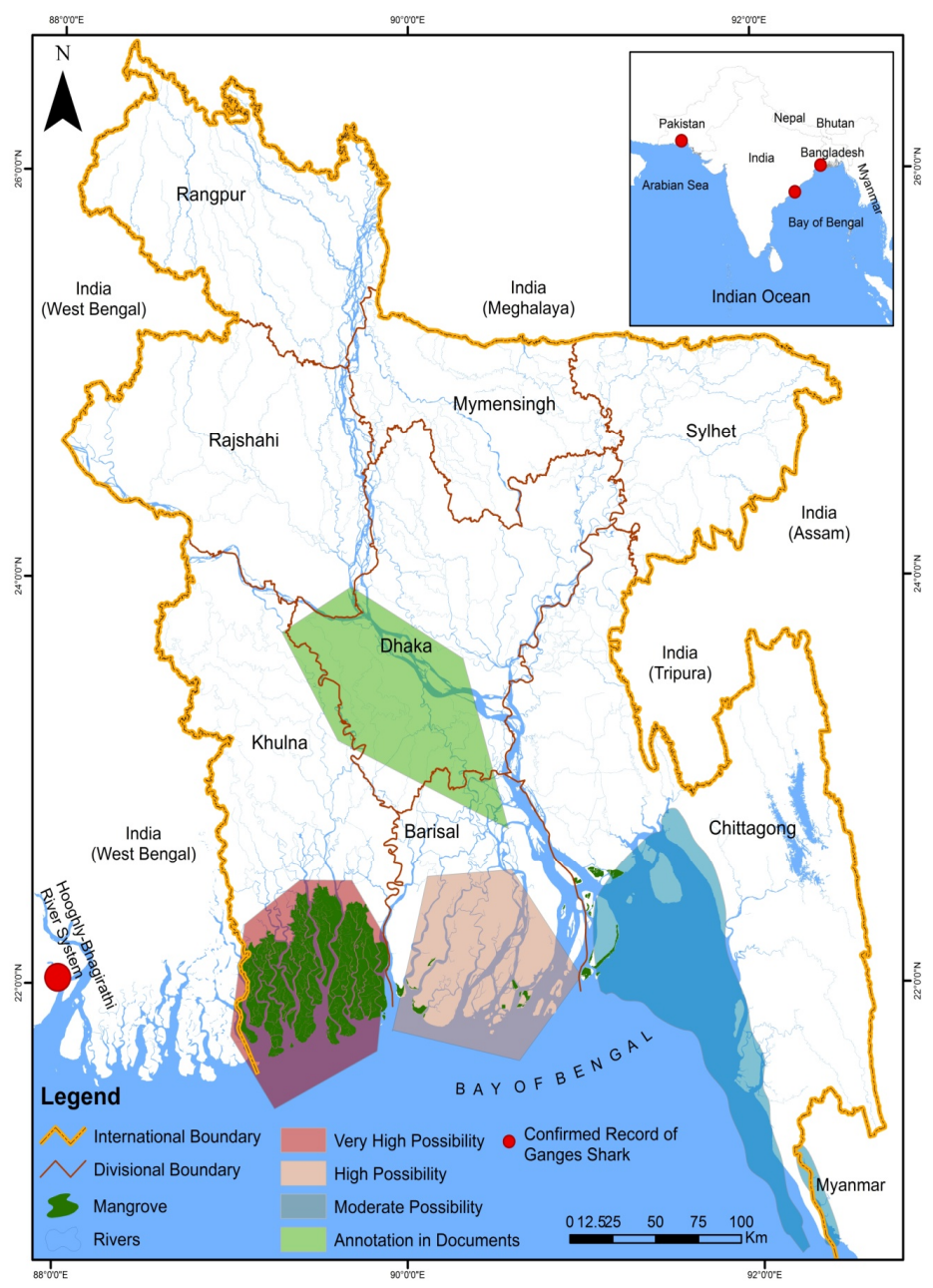

Fig. 2. Possible area of occupancy of Ganges Shark Glyphis gangeticus (Müller \& Henle, 1839) in Bangladesh.

Absence of strong knowledge inventory is possibly a major driver of dwindling status of this species, so as for the whole genus. The genus has an Indo-West Pacific distribution (2,3). Whereas, G. gangeticus has been so far described from the lower reaches of the Ganges-Hooghli River System, West Bengal, India and Karachi, Pakistan as shown in Fig. 2(2). Presence of two Glyphis species has been reported and three specimens of Glyphis glyphis were yielded from the Sundarbans ${ }^{(9,10)}$, yet a confirmed sighting or specimen of G. gangeticus is still wanting. 
Ecology and biology of the species is not properly documented to science. Small eyes and slender teeth though refer to a carnivorous habit and adaptation to turbid, murky water. The litter size and gestation period are not recorded, though considered as viviparous $^{(7)}$. However, their life history cycle is probably similar to other river sharks, characterized by long gestation, slow growth, delayed maturity, and small litter size ${ }^{(7)}$. It is also considered that G. gangeticus to be amphidromous, covering more than $100 \mathrm{~km}$ in both upstream and downstream ${ }^{(2,5,7)}$. The presence of newborn individuals in the Hooghly River suggests that the young may be born in freshwater.

In addition to recently revealed transoceanic gene flow in Glyphis sharks, hypotheses are also made shading lights on a migratory non-obligatory river dependency of the species ${ }^{(11-13)}$.

Glyphis sharks are, since last of the nineties, being under the spotlight of global-scale interest. On pursuit of this little-known but an epic example of evolutionary logbook, several attempts have been made, particularly by the denominator of carcharhinoid shark family and ardent shark taxonomist Leonard Compagno ${ }^{(2,4,6)}$. From India where the type specimen was discovered, a good depiction of habitat status and prediction of ecological parameters of Ganges Shark was provided ${ }^{(14)}$. In Bangladesh the species was annotated in publications in 2009 and $2015^{(5,15)}$.

G. gangeticus is one of the 20 sharks on the IUCN Global Red List of endangered shark species ${ }^{(7)}$. The species is currently classified as critically endangered(7). Glyphis gangeticus and G. glyphis are protected under Schedule 1 of the Wildlife (Protection) Act of India, 1972. However, the effectiveness of this measure is unknown and these regulations may be difficult to enforce, with a diffuse but widespread artisanal fishery on a major river system for local consumption as well as international trade(7). Drastic decreasing trend of Ganges Shark have been suspected due to several factors such as little known status though might be caused by Linnaean or Wallacean shortfall; elusiveness and range-restricted habitat; ecosystem stresses induced by anthropogenic activities; possible low reproduction rate, slow maturity, high mortality of juveniles; possible presence in the Oriental Fin Trade and in-shore fisheries (observation of jaws in international market during recent years) $)^{(2,7)}$.

Despite dwindling status of the species, the authors think there is a significant Wallacean shortfall about this species in Bangladesh. So far the three specimens of Glyphis glyphis have been reported from the vicinity of the Sundarbans, the largest single block of mangrove in world which is an ideal habitat of Glyphis sharks ${ }^{(10)}$. Scientific documentations on the habitat and ecology of Ganges Shark constitutes a hypothesis that the mangrove forest, lower branches of the Ganges on south-west and tidal rivers along the eastern coast of the Bay of Bengal might still support a population of this species. While the hypothesis persists, scientific expeditions and studies on the ecology and habitat of the species are indeed exigencies. Adequate researches such as molecular study 
as well as tagging and tracking the species will ultimately pave the way of bringing Ganges River Shark under conservation attention in the form of first shark sanctuary in Bangladesh, in the Sundarbans in particular.

\section{References}

1. Camhi M, SL Fowler, JA Musick, A Bräutigam and SV Fordham 1998. Sharks and their Relatives - Ecology and Conservation. IUCN SSC Shark Specialist Group. IUCN, Gland, Cambridge, pp. iv +39 .

2. Compagno LJV, M Dando and S Fowler 2005. Sharks of the world. Princeton University Press, Oxford. pp. 368.

3. Weighmann S 2016. Annotated checklist of the living sharks, batoids and chimaeras (Chondrichthyes) of the world, with a focus on biogeographical diversity. J. Fish. Biol. 88: 837-1037.

4. Compagno LJV, WT White and PR Last 2008. Glyphis garricki sp. nov., a new species of river shark (Carcharhiniformes: Carcharhinidae) from northern Australia and Papua New Guinea, with a redescription of Glyphis Glyphis (Müller \& Henle, 1839). In: Last PR, WT White and JJ Pogonosk (Eds), Descriptions of New Australian Chondrichthyans. CSIRO Marine \& Atmospheric Research Paper No. 022. pp. 203-225.

5. Hossain MA and N Sultana 2009. Glyphis gangeticus. In: Rahman AKA, SMH Kabir, M Ahmad, ATA Ahmed, ZU Ahmed, ZNT Begum, MA Hassan and M Khondker (Eds), Encyclopedia of flora and fauna of Bangladesh. Vol. 24. Marine Fishes. Asiat. Soc. Bangladesh. pp. 18-19.

6. Compagno LJV 1984. Sharks of the World. An annotated and illustrated catalogue of the shark species known to date. Vol. 2. (Carcharhiniformes). FAO Species Catalogue for Fisheries Purposes No.1. FAO, Rome. pp. 506-509.

7. Compagno LJV 2007. Glyphis gangeticus. The IUCN Red List of Threatened Species 2007. Retrieved from http://dx.doi.org/10.2305/IUCN.UK.2007.RLTS.T9281A12978210.en. Downloaded [Accessed on 6 October 2016].

8. Müller J and FGJ Henle 1841. Systematische Beschreibung der Plagiostoma. Veit, Berlin. pp. 200.

9. Hoq ME, AY Haroon and MG Hussain (Eds), 2011. Shark fisheries in the Bay of Bengal, Bangladesh: Status and potentialities. Support to Sustainable Management of the BOBLME Project, Bangladesh Fisheries Research Institute. pp. 76.

10. Bernacsek G and E Hoque 2001. Technical note on Endangered Sharks of the Sundarbans. Sundarban Biodiversity Conservation Project, Government of the People's Republic of Bangladesh and Asian Development Bank.

11. Roberts TR 2005. Debunking the mythology of the so-called freshwater shark of the Ganges. Glyphis gangeticus (Elasmobranchii, Carcharhinidae). The 7th Indo-Pacific Fish Conference, Academica Sinica: Ichythological Society of Taiwan, Taipei.

12. Li C, S Corrigan, L Yang, N Straube, M Harris, M Hofreiter, WT White and GJ Naylor 2015. DNA capture reveals transoceanic gene flow in endangered river sharks. Proceedings of the National Academy of Sciences 112(43): 13302-13307.

13. de Silva R 2011. Does the Ganges shark Glyphis gangeticus stray to Sri Lanka? J. Bombay Nat. Hist. Soc. 108(2): 136. 
14. Das S, S Zaman, T Rudra, P Pramanick and A Mitra 2015. Conservative pollutants in Ganges shark: A case study from the lower Gangetic delta region of Indian sub-continent. J. Chem., Biol. and Phys. S. 5(2): 1-12.

15. Roy BJ, NK Singha, MG Rhaman and AHMH Ali 2015. Status and record of sharks and rays in the Bay of Bengal of Bangladesh Region. Brazilian J. of Biol. S. 2(4): 343-367.

(Manuscript received on 26 December, 2016; revised on 19 January, 2017) 